\title{
Surface Modification on Ti-30Ta Alloy for Biomedical Application
}

\author{
Patricia Capellato ${ }^{1 *}$, Nicholas A. Riedel ${ }^{2}$, John D. Williams ${ }^{2}$, \\ Joao P. B. Machado ${ }^{3}$, Ketul C. Popat ${ }^{2,4}$, Ana P. R. Alves Claro ${ }^{1}$ \\ ${ }^{1}$ Department of Materials, UNESP — Univ. Estadual Paulista, Guaratinguetá, Brazil \\ ${ }^{2}$ Department of Mechanical Engineering, Colorado State University, Fort Collins, USA \\ ${ }^{3}$ Associated Laboratory of Sensors and Materials, INPE, São Jose dos Campos, Brazil \\ ${ }^{4}$ School of Biomedical Engineering, Colorado State University, Fort Collins, USA \\ Email: "pat_capellato@yahoo.com.br
}

Received May 13, 2013; revised June 13, 2013; accepted June 20, 2013

Copyright (C) 2013 Patricia Capellato et al. This is an open access article distributed under the Creative Commons Attribution License, which permits unrestricted use, distribution, and reproduction in any medium, provided the original work is properly cited.

\begin{abstract}
Titanium and titanium alloys are currently being used for clinical biomedical applications due to their high strength, corrosion resistance and elastic modulus. The Ti-30Ta alloy has gotten extensive application as the important biomedical materials. The substrate surface of the Ti-30Ta alloy was altered either by chemical or topographical surface modification. The biocompatibility of an implant is closely related to its surface properties. Thus surface modification is one of effective methods for improving the biocompatibility of implants. The development status of biomedical materials has been summarized firstly, as the biomedical application. In this study Ti-30Ta alloy surface was investigated as-casting (Group 1) modified with alkaline and heat-treatments in $\mathrm{NaOH}$ with $1.5 \mathrm{M}$ at $60^{\circ} \mathrm{C}$ for 24 hrs (Group 2), alkaline and heat-treatments with SBF-coatings by immersion in $\mathrm{NaOH}$ and SBFX5 for 24hrs (Group 3), anodization process was performed in an electrolyte solution containing HF (48\%) and H2SO4 (98\%) with the addition of 5\% dimethyl sulfoxide (DMSO) 35V for 40 min (Group 4) and ion beam etching with $1200 \mathrm{eV}$ ions with a beam current of $200 \mathrm{~mA}$ for a 3 hrs etch (Group 5). SEM was used to investigate the topography, EDS the chemical composition, and surface energy was evaluated with water contact angle measurement. SEM results show different structure on the surface for each group. EDS spectra identified similarity on Group 1, 4 and 5. The results indicate for group 2 an amorphous sodium tantalate hydrogel layer on the substrate surface and for group 3 the apatite nucleation on substrate surface. The Group 4 shows unorganized and vertically nanotubes and Group 5 shows a little alteration in the topography on the substrate surfaces. Overall the contact angle shows Group 5 the most hydrophobic and Group 4 the most hydrophilic. The study indicates Group 3 and 4 with potential for biomedical application. The next step the authors need to spend more time to study group 3 and 4 in the biomedical sciences.
\end{abstract}

Keywords: Biocompatibility; Ti-30Ta Alloy; Alkali Treatment; Heat Treatment; Simulated Body Fluid; Anodization Process; Ion Beam Etching

\section{Introduction}

Metallic materials have been used as implantable for orthopedic and dental implants. Materials such as steel, cobalt alloys and titanium and titanium alloys are currently being used in clinical biomedical applications due to their high strength, corrosion resistance and elastic modulus [1-6]. However, these materials have recently been shown to exhibit ion release and poor physiological integration that may result in fibrous encapsulation and further biomaterial rejection $[3,7,8]$. In order to be a successful replacement for bone a biomaterial must be bio-

"Corresponding author. compatible, corrosion resistant, exhibit a high strength, and a low elastic modulus [1-6]. Current approaches for enhancing the mechanical and biological properties of $\mathrm{Ti}$ alloys include add elements such as $\mathrm{Nb}, \mathrm{Ta}, \mathrm{Zr}, \mathrm{Mo}, \mathrm{Hf}$ and Sn [4,9-23]. Among these candidates, titanium (Ti) alloyed with tantalum (Ta) will be considered in this study due to it provides greatly improved mechanical properties which include fracture toughness and workability, shows improvement from both pure $\mathrm{Ti}$ and pure Ta [18,24-27]. In addition, using 30\% of tantalum has been shown to produce a strong effect on both young's modulus and the tensile properties of binary Ti-Ta alloys. Unique to other Ti-Ta alloys, the Ti-30Ta alloy provides 
a martensite " $\alpha$ " phase that produces a good combination of low modulus and high strength [9-13,21,24,25,28]. The interaction between the implant surface and the tissue plays an important role on the success of this implantable device $[3,7,29]$. Several studies have shown that by modifying the surface at a nanoscale or a microscale it can alter cellular response [20,30-32]. Studies have shown techniques such ion beam etching [33,34], heat and alkaline treatment $[15,17,35]$, SBF coatings [16, 36-38] and anodization [39-41] to promote altered cellular response on $\mathrm{Ti}$ and Ti-alloys. One effective parameter to evaluate the biological response of the metallic biomaterials is investigating the wettability of the surface of this material due to the topography having effect on protein adsorption, platelet adhesion, blood coagulation and bacterial adhesion [42-45]. In this study, the substrate surface of the Ti-30Ta alloy was altered either by chemical or topographical surface modification. The Ti-30Ta alloy substrates were modified with alkaline and heattreatments, alkaline and heat-treatments with simulated body fluid (SBF) coatings, anodization process and ion beam etching. Following techniques were used for characterizing all groups: scanning electron microscopy (SEM), energy dispersive spectroscopy (EDS) and contact angle analyze.

\section{Materials and Method}

\subsection{Fabrication of Ti-30Ta Alloy}

Ti (99\%) and Ta (99\%) were combined by a melting process in a high purity argon atmosphere; re-melted ten times and held in the molten state for 3 - 4 minutes due to the titanium and tantalum there are differing densities (Ti: $1953 \mathrm{~K}, 4.51 \mathrm{~g} / \mathrm{cm}^{3}$ and Ta: $\left.3273 \mathrm{~K}, 16.6 \mathrm{~g} / \mathrm{cm}^{3}\right)$ and the wide-phase differential (liquid and solid) in the binary Ti-Ta phase diagram [9-13,22,25]. All ingots were homogenized in a vacuum at $1100^{\circ} \mathrm{C}$ for $86.4 \mathrm{ks}$ in order to eliminate the as-cast microscopic chemical segregation and the residual stress caused by plastic deformation on the elastic modulus. The alloy was then cold-worked by a rotary swaging process (rotation speed $1000 \mathrm{rpm}$ ) using a CNC lathe ZIL (Centur 30S, ROMY, Brazil) [45] and cut in discs. The Ti-30Ta alloy substrates were then separated into five groups for this study: Group 1: Ti-30Ta alloy substrates control, Group 2: Ti-30Ta alloy substrates with alkaline and heat-treated, Group 3: Ti-30Ta alloy substrates with alkaline and heat-treatments with SBF-coatings, Group 4: Ti-30Ta alloy substrates submitted to anodization process, and Group 5: Ti-30Ta alloy substrates after etching (See Table 1).

\subsection{Alkaline and Heat Treatments on the Ti-30Ta Alloy Surface (Group 2)}

The control substrate surface was used as-fabricated
Table 1. Ti-30Ta alloy substrates were separated into three groups: Group 1: Ti-30Ta alloy substrates control, Group 2: Ti-30Ta alloy substrates with alkaline and heat-treat- ments and Group 3: Ti-30Ta alloy substrates with alkaline and heat-treatments with SBF-coatings, Group 4: Ti-30Ta alloy substrates submitted to anodization process and Group 5: Ti-30Ta alloy substrates after etched by plasma.

\begin{tabular}{ccccc}
\hline Group 1 & Group 2 & Group 3 & Group 4 & Group 5 \\
\hline Ti-30Ta alloy $\mathrm{NaOH}+\mathrm{HT}$ & $\begin{array}{c}\mathrm{NaOH}+\mathrm{HT} \\
+\mathrm{SBF}\end{array}$ & $\begin{array}{c}\text { Anodization } \\
\text { process }\end{array}$ & $\begin{array}{c}\text { Ion beam } \\
\text { etching }\end{array}$ \\
\hline
\end{tabular}

(Group 1). Group 2 substrates were alkaline-treated by soaked in $5.0 \mathrm{ml}$ of $\mathrm{NaOH}$ (aqueous solution) with $1.5 \mathrm{M}$ at $60^{\circ} \mathrm{C}$ for $24 \mathrm{hrs}$ and dried at $40^{\circ} \mathrm{C}$ for $24 \mathrm{hrs}[15-17,19$, 46]. The substrates were further heated to $300^{\circ} \mathrm{C}$ in an electric furnace (air atmosphere) at a rate of $5^{\circ} \mathrm{C} / \mathrm{min}$ for $1 \mathrm{hr}[16,17]$ and cooled to room temperature within the furnace.

\subsection{SBF Coatings on Ti-30Ta Alloy Surface (Group 3)}

Group 3 substrates were alkaline and heat treated [16,17] and incubation on $30 \mathrm{ml}$ of SBFx 5 with ion concentrations and $\mathrm{pH}$ is comparable to that of human blood plasma at $36.5^{\circ} \mathrm{C}$. Previous studies have identified SBFx 5 [38] solution to accelerated the deposition of biomimetic Ca-P. The SBFx5 was prepared using the protocol described in publish literature [38].

\subsection{Anodization of Ti-30Ta Alloy Surface (Group 4)}

Group 4 substrates were fabricated by anodization process using platinum as the cathode and the Ti-30Ta as the anode. The electrolyte solution composed of concentrate $\mathrm{HF}(48 \%)$ and $\mathrm{H}_{2} \mathrm{SO}_{4}(98 \%)$ in the volumetric ratios $1: 9$ with the addition of $5 \%$ dimethyl sulfoxide (DMSO), stirred constantly. The experiment was conducted in constant voltage of $35 \mathrm{~V}$ during 40 minutes at room temperature. The substrates were cleaned with isopropyl and dried with compressed air. The substrates were then sintered in an electric furnace with oxygen ambient at $530^{\circ} \mathrm{C}$ rate of $1^{\circ} \mathrm{C} / \mathrm{min}$ for $3 \mathrm{hrs}$.

\subsection{Ion beam Etching of Ti-30Ta Alloy Surface (Group 5)}

Group 5 substrates were fabricated by etching the alloy surface to oblique angle oxygen ion beam by increasing the oxygenation of the near surface regions. Etching was done with a $16 \mathrm{~cm}$ ion source in a low-pressure environment (approximately $1.6 \times 10^{-4}$ Torr). Gas flow rates through the source and neutralizer were $20 \mathrm{sccm} \mathrm{O} \mathrm{O}_{2}$ and $8 \mathrm{sccm}$ Ar respectively. An energetic ion beam of 1200 $\mathrm{eV}$ ions with a beam current of $200 \mathrm{~mA}$ was used for a 3 
hour etch. This beam consisted primarily of oxygen ions though it is possible that minute amounts of background Ar gas could diffuse into the source, ionize and be included. The substrates were placed on an inclined holder so the resulting angle of ion incidence was approximately 75 degrees from the surface normal [33].

\subsection{Physical Characterization of Different Groups}

The Ti-30Ta alloy substrates surfaces were examined before and after the surface modification. The surface topography of the substrates was characterized by coating the surface with $15 \mathrm{~nm}$ of gold and using a JEOL JSM-6500FESEM at a working distance of $10 \mathrm{~cm}$ and a voltage of $15 \mathrm{kV}$. The surface elemental composition of the Ti-30Ta alloy substrates was further characterized with energy-dispersive X-ray spectroscopy (EDS, JSM6500F SEM). Wettabilities of the modified surfaces were determined by measuring water contact angle (FTA1000B Class, First Ten Angstroms, Inc.). A $2 \mu$ droplet of distilled water was dropped on the surface. Immediately after this the droplet images captured using a camera. The image was then processed with the ac- companying Fta32 software determine give contact angle and the droplet volume. All the studies were conducted for minimum 6 samples to ensure appropriate statistical variability.

\section{Results and Discussion}

The binary Ti-30Ta alloy was fabricated by mixing highpurity sponge $\mathrm{Ti}(99 \%)$ and $\mathrm{Ta}(99 \%)$ by melting and homogenized in a vacuum. It was Cold-worked by a rotary swaging process and further cut to working size. Ti-30Ta alloy substrate surface control was formed by the martensite $\alpha$ " seems to produce a needle-like structure that result in the elastic modulus of $69 \mathrm{GPa}$ and a tensile strength of the $587 \mathrm{MPa}$ with resulting in strengthto-modulus ratio of 8.51 [13]. Recent studies have shown the Ti-30Ta alloy substrates (control) to possess the lamellar and needle-like morphology of the $\alpha$-phase [21, $22]$, therefore theses results indicate enables strong mechanical properties and improved corrosion resistance [913,18,25] SEM images for Group 1 (Figure 1 (a)) were taken at 25000X. Figure 1(c) represent the SEM images for group 2 were taken at $25000 \mathrm{X}$. The amorphous sodium tantalato layer was observed on Ti-30Ta alloy after alkaline treatment with $1.5 \mathrm{M}$ at $60^{\circ} \mathrm{C}$ for $24 \mathrm{hrs}$ and heat treatment $300^{\circ} \mathrm{C}$ for $1 \mathrm{hr}$. The images shows microporous structures with sizes within 50 - $100 \mathrm{~nm}$ [47] with cracks uniforms covering all surface [15-17,35-37]. The substrate have different coefficient of expansion that the layer amorphous sodium tantalate formed that results in cracks during the dry in heat treatment $[35,48]$. Figure 1(e) shows SEM images of Group 3 taken at 25000X with long and confluent particles. The image identified presence of apatite formed on Ti-30Ta alloy substrate after immersion in SBF for $24 \mathrm{hrs}$ covered all substrate. The tantalum metal with alkaline and heat treatment and exposed to SBFx5 shows that the sodium tantalate exchanges its $\mathrm{Na}^{+}$ion with $\mathrm{H}_{3} \mathrm{O}^{+}$ion in the $\mathrm{SBF}$ in order to outcome Ta-OH groups. The nucleation of heterogeneous apatite was formed by the Ta-OH groups. Figure 1(g) shows SEM images for Group 4 taken at 50000X. The results show unorganized nanotubes with $100 \mathrm{~nm}$ of the diameter which are not aligned. Figure 1(i) shows SEM images for Group 5 taken at 50000X. The results show formation of nanoscale spheroids with a wavy surface architecture. Further, the results indicate that the ion etching did not significantly alter the surface. It seems that etching at $1200 \mathrm{eV}$ was not enough to significantly change the surface topography [33]. EDS spectra for Group 1 (Figure 1(b)), Group 4 (Figure 1(h)) and Group 5 (Figure 1(j)) showed peaks for titanium and tantalum. Group 2 (Figure 1(d)) showed peaks for titanium, tantalum and oxygen. Group 3 (Figure 1(f)) showed peaks of titanium, tantalum, calcium and sodium. Due to gold coating layer on the surface the phosphorous was not detected by EDS since the phosphorous and gold peaks overlap. Figure 2 shows contact angle measurements on different groups. The results indicate following order of surface hydrophilicity (Figure 2):

Group $4>$ Group $2>$ Group $3>$ Group $1>$ Group 5

This behavior is extremely important since cell and bacterial adhesion, protein adsorption, platelet adhesion and activation and blood coagulation may be affected. The materials for biomedical application need to be more hydrophilic since they have higher surface energy which is desirable for biological interaction $[43,45,49]$.

\section{Conclusion}

In this study, the Ti-30Ta alloy substrates were modified chemically as well as topographically. The surfaces were modified by treating the substrates with alkaline and heat treatment, alkaline and heat-treatments with SBF-coatings, anodization process and ion beam etching. SEM results show different structure on the surface for each group. EDS spectra identified similarity on Groups 1, 4 and 5. The results presented here indicate for Group 2 an amorphous sodium tantalate hydrogel layer on the substrate surface and for Group 3 the apatite nucleation on substrate surface. The Group 4 shows unorganized and vertically nanotubes and Group 5 shows a little alteration in the topography on the substrate surfaces. Overall the contact angle shows Group 5 the most hydrophobic and Group 4 the most hydrophilic. In conclusion, the study indicates Groups 3 and 4 are the more indicated for biomedical application. The current research is now focused 

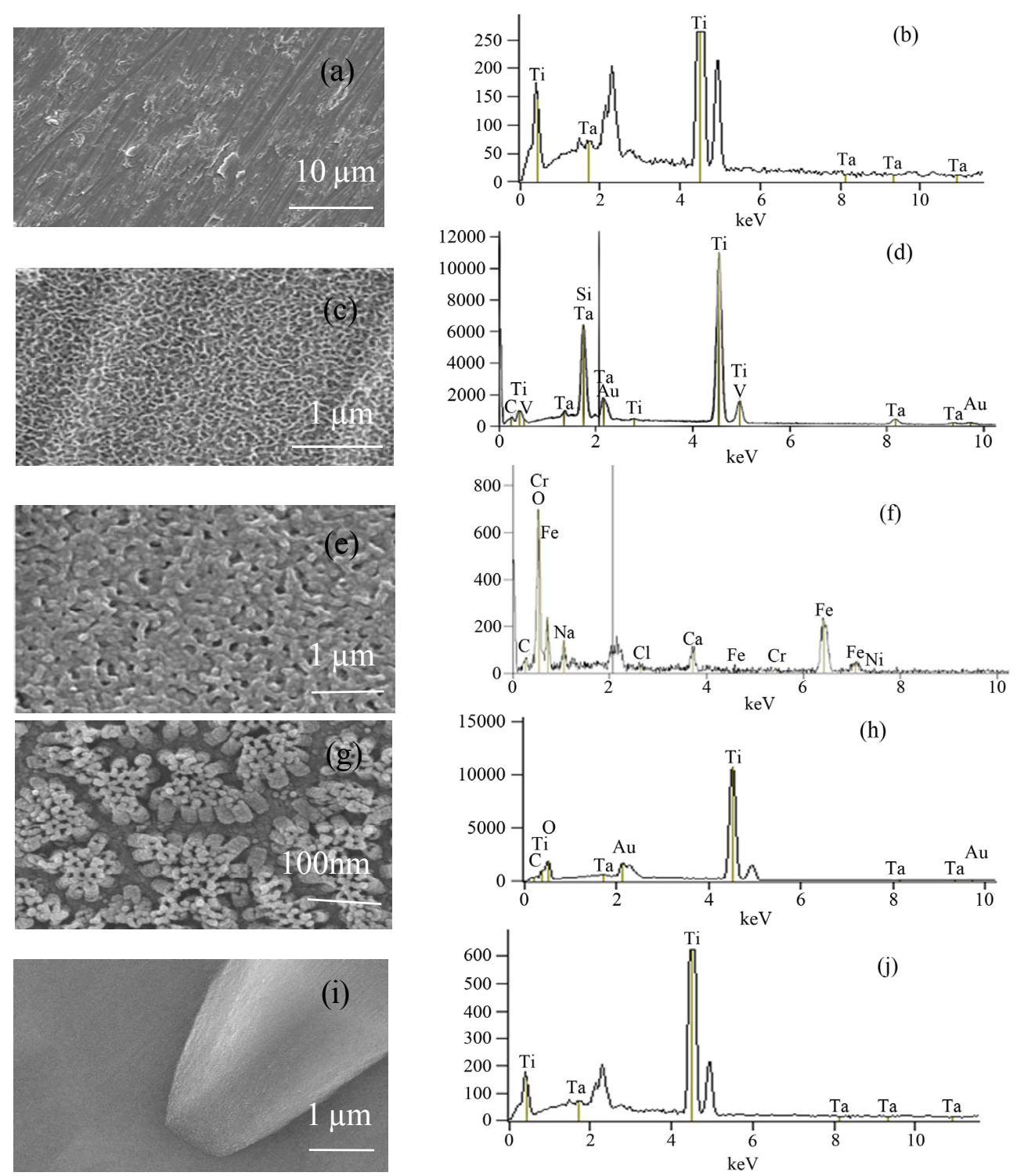

Figure 1. SEM images (left) and EDS scans (right) for Ti-30Ta alloy Group 1: Ti-30Ta alloy substrates control ((a), (b)), Group 2: Ti-30Ta alloy substrates with alkaline and heat-treatments ((c), (d)), Group 3: Ti-30Ta alloy substrates with alkaline and heat-treatments with SBF-coatings ((e), (f)) with 25000X magnificence. Group 4: Ti-30Ta alloy substrates anodized to form nanotubes ((g), (h)), and Group 5: Ti-30Ta alloy substrates after etch ((i), (j)) taking in 5000× magnificence

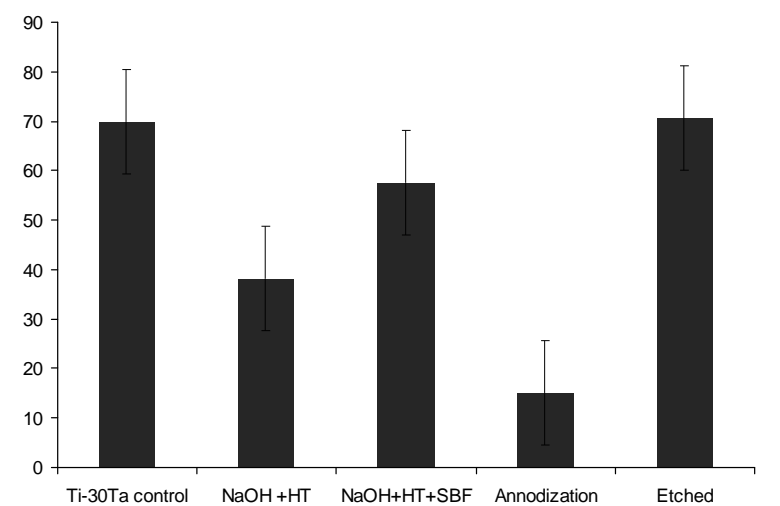

Figure 2. Contact angle measurements on surfaces of different groups. on evaluating biological response on these surfaces.

\section{Acknowledgements}

Partial funding support for this work was provided by Brazilian agencies CNPq via grant Doctored sandwich (201271/2010-9) and Fapesp project number 2010/ 10174-8 and 2010/07231-0. The authors thank Patrick McCurdy for your assistance.

\section{REFERENCES}

[1] B. P. M. Bannon and E. E. Titanium, "Alloys in Surgical Implants. Titanium Alloys for Biomaterial Application: An Overview," 1983. 
[2] J. E. Ellingsen, P. Thomsen and S. P. Lyngstadaas, "Advances in Dental Implant Materials and Tissue Regeneration," Periodontology 2000, Vol. 41, No. 1, 2006, pp. 136-156. doi:10.1111/j.1600-0757.2006.00175.x

[3] M. Geetha, A. K. Singh, R. Asokamani and A. K. Gogia, "Ti Based Biomaterials, the Ultimate Choice for Orthopaedic Implants-A Review," Progress in Materials Science, Vol. 54, No. 3, 2009, pp. 397-425.

doi:10.1016/j.pmatsci.2008.06.004

[4] X. Liu, P. K. Chu and C. Ding, "Surface Modification of Titanium, Titanium Alloys, and Related Materials for Biomedical Applications," Materials Science and Engineering: A, Vol. 47, No. 3-4, 2004, pp. 49-121. doi:10.1016/j.mser.2004.11.001

[5] M. Niinomi, "Mechanical Biocompatibilities of Titanium Alloys for Biomedical Applications," Journal of the Mechanical Behavior of Biomedical Materials, Vol. 1, No. 1, 2008, pp. 30-42. doi:10.1016/j.jmbbm.2007.07.001

[6] K. Wang, "The Use of Titanium for Medical Applications in the USA," Materials Science and Engineering, Vol. 213, No. 1, 1996, pp. 134-137. doi:10.1016/0921-5093(96)10243-4

[7] J. O. Galante, J. Lemons, M. Spector, P. D. Wilson and T. M. Wright, "The Biologic Effects of Implant Materials," Journal of Orthopaedic Research, Vol. 9, No. 5, 1991, pp. 760-775. doi:10.1002/jor.1100090516

[8] C. Palma-Carrió, D. Peñarrocha-Oltra, M. A. PeñarrochaDiago and M. Peñarrocha-Diago, "Risk Factors Associated with Early Failure of Dental Implants-A Literature Review," Medicina Oral Patologia Oral y Cirugia Bucal, Vol. 16, No. 4, 2011, pp. 514-517. doi:10.4317/medoral.16.e514

[9] Y. L. Zhou and M. Niinomi, "Ti-25Ta Alloy with the Best Mechanical Compatibility in Ti-Ta Alloys for Biomedical Applications," Materials Science and Engineering: $C$, Vol. 29, No. 3, 2009, pp. 1061-1065. doi:10.1016/j.msec.2008.09.012

[10] Y. L. Zhou and M. Niinomi, "Microstructures and Mechanical Properties of Ti-50 Mass\% Ta Alloy for Biomedical Applications," Journal of Alloys and Compounds, Vol. 466, No. 1-2, 2008, pp. 535-542. doi:10.1016/j.jallcom.2007.11.090

[11] Y. L. Zhou, M. Niinomi and T. Akahori, "Changes in Mechanical Properties of Ti Alloys in Relation to Alloying Additions of Ta and Hf," Materials Science and Engineering: A, Vol. 483-484, 2008, pp. 153-156. doi:10.1016/j.msea.2006.09.173

[12] Y. L. Zhou, M. Niinomi and T. Akahori, "Decomposition of Martensite [Alpha] during Aging Treatments and Resulting Mechanical Properties of Ti-Ta Alloys," Materials Science and Engineering A, Vol. 384, No. 1-2,2004, pp. 92-101. doi:10.1016/j.msea.2004.05.084

[13] Y. L. Zhou, M. Niinomi and T. Akahori, "Effects of Ta Content on Young's Modulus and Tensile Properties of Binary Ti-Ta Alloys for Biomedical Applications," Materials Science and Engineering A, Vol. 371, No. 1-2, 2004, pp. 283-290. doi:10.1016/j.msea.2003.12.011

[14] M. Niinomi, "Recent Metallic Materials for Biomedical
Applications," Metallurgical and Materials Transactions A, Vol. 33, No. 3, 2002, pp. 477-486. doi:10.1007/s11661-002-0109-2

[15] T. Miyazaki, H. M. Kim, F. Miyaji, T. Kokubo, H. Kato and T. Nakamura, "Bioactive Tantalum Metal Prepared by $\mathrm{NaOH}$ Treatment," Journal of Biomedical Materials Research, Vol. 50, 2000, pp. 35-42. doi:10.1002/(SICI)1097-4636(200004)50:1<35::AID-JB $\mathrm{M} 6>3.0 . \mathrm{CO} ; 2-8$

[16] T. Miyazaki, H. M. Kim, T. Kokubo, C. Ohtsuki, H. Kato and T. Nakamura, "Enhancement of Bonding Strength by Graded Structure at Interface between Apatite Layer and Bioactive Tantalum Metal," Journal of Materials Science. Materials in Medicine, Vol. 13, No. 7, 2002, pp. 651-655. doi:10.1023/A:1015729507800

[17] T. Miyazaki, H. M. Kim, T. Kokubo, C. Ohtsuki, H. Kato and T. Nakamura, "Effect of Thermal Treatment on Apatite-Forming Ability of $\mathrm{NaOH}-$ Treated Tantalum Metal," Journal of Materials Science: Materials in Medicine, Vol. 12, No. 8, 2001, pp. 683-687. doi:10.1023/A:1011260224120

[18] D. Mareci, R. Chelariu, D.-M. Gordin, G. Ungureanu and T. Gloriant, "Comparative Corrosion Study of Ti-Ta Alloys for Dental Applications," Acta Biomaterialia, Vol. 5, No. 9, 2009, pp. 3625-3639. doi:10.1016/j.actbio.2009.05.037

[19] D. Wei, Y. Zhou, D. Jia and Y. Wang, "Structure of Calcium Titanate/Titania Bioceramic Composite Coatings on Titanium Alloy and Apatite Deposition on Their Surfaces in a Simulated Body Fluid," Surface and Coatings Technology, Vol. 201, No. 21, 2007, pp. 8715-8722. doi:10.1016/j.surfcoat.2007.04.124

[20] F. Variola, F. Vetrone, L. Richert, P. Jedrzejowski, J.-H. $\mathrm{Yi}, \mathrm{S}$. Zalzal, et al., "Improving Biocompatibility of Implantable Metals by Nanoscale Modification of Surfaces: An Overview of Strategies, Fabrication Methods, and Challenges," Small, Vol. 5, No. 9, 2009, pp. 996-1006. doi:10.1002/smll.200801186

[21] E. Eisenbarth, D. Velten, M. Müller, R. Thull and J. Breme, "Biocompatibility of [Beta]-Stabilizing Elements of Titanium Alloys," Biomaterials, Vol. 25, No. 26, 2004, pp. 5705-5713. doi:10.1016/j.biomaterials.2004.01.021

[22] G. Jianting, D. Ranucci and F. Gherardi, "Precipitation of $\beta$ Phase in the $\gamma$ ' Particles of Nickel-Base Superalloy," Metallurgical and Materials Transactions A, Vol. 15, No. 7, 1984, pp. 1331-1334. doi:10.1007/BF02648561

[23] Z. Cai, M. Koike, H. Sato, M. Brezner, Q. Guo, M. Komatsu, et al., "Electrochemical Characterization of Cast Ti-Hf Binary Alloys," Acta Biomaterialia, Vol. 1, No. 3, 2005, pp. 353-356. doi:10.1016/j.actbio.2005.02.006

[24] P. Gill, N. Munroe, C. Pulletikurthi, S. Pandya and W. Haider, "Effect of Manufacturing Process on the Biocompatibility and Mechanical Properties of Ti-30Ta Alloy," Journal of Materials Engineering and Performance, Vol. 20, No. 4, 2011, pp. 819-823. doi:10.1007/s11665-011-9874-7

[25] Y. L. Zhou, M. Niinomi, T. Akahori, H. Fukui and H. Toda, "Corrosion Resistance and Biocompatibility of Ti- 
Ta Alloys for Biomedical Applications," Materials Science and Engineering A, Vol. 398, No. 1-2, 2005, pp. 2836. doi:10.1016/j.msea.2005.03.032

[26] Y. Tong, B. Guo, Y. Zheng, C. Chung and L. Ma, "Effects of $\mathrm{Sn}$ and $\mathrm{Zr}$ on the Microstructure and Mechanical Properties of Ti-Ta-Based Shape Memory Alloys," Journal of Materials Engineering and Performance, Vol. 20, No. 4-5, 2011, pp. 762-766. doi:10.1007/s11665-010-9817-8

[27] T. Gloriant, G. Texier, F. Prima, D. Laillé, D. M. Gordin, I. Thibon, et al., "Synthesis and Phase Transformations of Beta Metastable Ti-Based Alloys Containing Biocompatible Ta, Mo and Fe Beta-Stabilizer Elements," $A d$ vanced Engineering Materials, Vol. 8, No. 10, 2006, pp. 961-965. doi:10.1002/adem.200600106

[28] A. Dobromyslov, G. Dolgikh, Y. Dutkevich and T. Trenogina, "Phase and Structural Transformations in Ti-Ta Alloys," The Physics of Metals and Metallography, Vol. 107, No. 5, 2009, pp. 502-510. doi:10.1134/S0031918X09050111

[29] B. S. Smith, S. Yoriya, L. Grissom, C. A. Grimes and K. C. Popat, "Hemocompatibility of Titania Nanotube Arrays," Journal of Biomedical Materials Research Part A, Vol. 95A, No. 2, 2010, pp. 350-360. doi:10.1002/jbm.a.32853

[30] X. J. Wang, Y. C. Li, J. G. Lin, Y. Yamada, P. D. Hodgson and C. E. Wen, "In Vitro Bioactivity Evaluation of Titanium and Niobium Metals with Different Surface Morphologies," Acta Biomaterialia, Vol. 4, No. 5, 2008, pp. 1530-1535. doi:10.1016/j.actbio.2008.04.005

[31] P. Habibovic, T. M. Sees, M. A. van den Doel, C. A. van Blitterswijk and K. de Groot, "Osteoinduction by Biomaterials-Physicochemical and Structural Influences," Journal of Biomedical Materials Research Part A, Vol. 77A, No. 4, 2006, pp. 747-762. doi:10.1002/jbm.a.30712

[32] T. Kokubo, H. M. Kim, M. Kawashita, "Novel Bioactive Materials with Different Mechanical Properties," Biomaterials, Vol. 24, No. 13, 2003, pp. 2161-2175. doi:10.1016/S0142-9612(03)00044-9

[33] A. Nicholas, J. D. W. Riedel and C. Ketul Popat, "Ion Beam Etching Titanium for Enhanced Osteoblast Response," Journal Material Science, Vol. 46, No. 18, 2011, pp. 6087-6095. doi:10.1007/s10853-011-5571-Z

[34] E. Martínez, E. Engel, J. A. Planell and J. Samitier, "Effects of Artificial Micro- and Nano-Structured Surfaces on Cell Behaviour," Annals of Anatomy-Anatomischer Anzeiger, Vol. 191, No. 1, 2009, pp. 126-135. doi:10.1016/j.aanat.2008.05.006

[35] H.-M. Kim, F. Miyaji, T. Kokubo and T. Nakamura, "Preparation of Bioactive Ti and Its Alloys via Simple Chemical Surface Treatment," Journal of Biomedical Materials Research, Vol. 32, No. 3, 1996, pp. 409-417. doi:10.1002/(SICI) 1097-4636(199611)32:3<409::AID-JB M14>3.0.CO;2-B

[36] H. Kato, T. Nakamura, S. Nishiguchi, Y. Matsusue, M. Kobayashi, T. Miyazaki, et al., "Bonding of Alkali- and Heat-Treated Tantalum Implants to Bone," Journal of Biomedical Materials Research, Vol. 53, No. 1, 2000, pp. 28-35.
doi:10.1002/(SICI)1097-4636(2000)53:1<28::AID-JBM4 3.0.CO;2-F

[37] T. Miyazaki, H.-M. Kim, T. Kokubo, C. Ohtsuki, H. Kato and T. Nakamura, "Mechanism of Bonelike Apatite Formation on Bioactive Tantalum Metal in a Simulated Body Fluid," Biomaterials, Vol. 23, No. 3, 2002, pp. 827-832. doi:10.1016/S0142-9612(01)00188-0

[38] F. Barrere, C. A. van Blitterswijk, K. de Groot and P. Layrolle, "Influence of Ionic Strength and Carbonate on the Ca-P Coating Formation from $\mathrm{SBF} \times 5$ Solution," Biomaterials," Vol. 23, No. 9, 2002, pp. 1921-1930. doi:10.1016/S0142-9612(01)00318-0

[39] C. Han-Cheol, "Nanotubular Surface and Morphology of Ti-Binary and Ti-Ternary Alloys for Biocompatibility," Thin Solid Films, Vol. 519, No. 15, 2011, pp. 4652-4657. doi:10.1016/i.tsf.2011.01.011

[40] H. Tsuchiya, T. Akaki, J. Nakata, D. Terada, N. Tsuji, Y. Koizumi, et al., "Anodic Oxide Nanotube Layers on TiTa Alloys: Substrate Composition, Microstructure and Self-Organization on Two-Size Scales," Corrosion Science, Vol. 51, No. 7, 2009, pp. 1528-1533. doi:10.1016/j.corsci.2008.11.011

[41] N. K. Allam, X. J. Feng and C. A. Grimes, "Self-Assembled Fabrication of Vertically Oriented $\mathrm{Ta}_{2} \mathrm{O}_{5}$ Nanotube Arrays, and Membranes Thereof, by One-Step Tantalum Anodization," Chemistry of Materials, Vol. 20, No. 20, 2008, pp. 6477-6481. doi:10.1021/cm801472y

[42] J.-H. Choee, S. J. Lee, Y. M. Lee, J. M. Rhee, H. B. Lee and G. Khang, "Proliferation Rate of Fibroblast Cells on Polyethylene Surfaces with Wettability Gradient," Journal of Applied Polymer Science, Vol. 92, No. 1, 2004, pp. 599-606. doi:10.1002/app.20048

[43] G. Zhao, Z. Schwartz, M. Wieland, F. Rupp, J. GeisGerstorfer, D. L. Cochran, et al., "High Surface Energy Enhances Cell Response to Titanium Substrate Microstructure," Journal of Biomedical Materials Research Part A, Vol. 74, No. 1, 2005, pp. 49-58. doi: $10.1002 / \mathrm{jbm} . \mathrm{a} .30320$

[44] L. Le Guéhennec, A. Soueidan, P. Layrolle and Y. Amouriq, "Surface Treatments of Titanium Dental Implants for Rapid Osseointegration,” Dental Materials, Vol. 23, No. 7, 2007, pp. 844-854. doi:10.1016/j.dental.2006.06.025

[45] A. L. A. Escada, D. Rodrigues Jr., J. P. B. Machado and A. P. R. A. Claro, "Surface Characterization of Ti-7.5Mo Alloy Modified by Biomimetic Method," Surface and Coatings Technology, Vol. 205, No. 2, 2010, pp. 383-387. doi:10.1016/j.surfcoat.2010.06.067

[46] M. Wei, M. Uchida, H.-M. Kim, T. Kokubo and T. Nakamura, "Apatite-Forming Ability of CaO-Containing Titania," Biomaterials, Vol. 23, No. 1, 2002, pp. 167-172. doi:10.1016/S0142-9612(01)00092-8

[47] W.-F. Ho, W.-K. Chen, S.-C. Wu and H.-C Hsu, "Structure, Mechanical Properties, and Grindability of Dental Ti-Zr Alloys," Journal of Materials Science: Materials in Medicine, Vol. 19, No. 10, 2008, pp. 3179-3186. doi:10.1007/s10856-008-3454-x

[48] H. B. Wen, J. G. C. Wolke, J. R. de Wijn, Q. Liu, F. Z. Cui and K. de Groot, "Fast Precipitation of Calcium 
Phosphate Layers on Titanium Induced by Simple Chemical Treatments," Biomaterials, Vol. 18, No. 22, 1997, pp. 1471-1478. doi:10.1016/S0142-9612(97)82297-1

[49] O. Zinger, K. Anselme, A. Denzer, P. Habersetzer, M. Wieland, J. Jeanfils, et al., "Time-Dependent Morphology and Adhesion of Osteoblastic Cells on Titanium Model Surfaces Featuring Scale-Resolved Topography," Biomaterials, Vol. 25, No. 14, 2004, pp. 2695-2711. doi:10.1016/j.biomaterials.2003.09.111 